\title{
Salicylate Phenanthroline copper (II) complex induces apoptosis in triple-negative breast cancer cells
}

\author{
Limei Fan ${ }^{1,2, *}$, Muyou Tian ${ }^{3, *}$, Yunyi Liu ${ }^{1,2, *}$, Ying Deng ${ }^{1,2}$, Zhengkai Liao ${ }^{3,4}$, Jinhua Xu ${ }^{1,2}$ \\ ${ }^{1}$ School of Medicine, Jianghan University, Wuhan, Hubei 430056, China \\ ${ }^{2}$ Key Laboratory of Optoelectronic Chemical Materials and Devices, Ministry of Education, Jianghan University, Wuhan, Hubei \\ 430056, China \\ ${ }^{3}$ Department of Radiation and Medical Oncology, Zhongnan Hospital, Wuhan University, Wuhan, Hubei 430071, China \\ ${ }^{4}$ Hubei Key Laboratory of Tumor Biological Behavior, Wuhan University, Wuhan, Hubei 430071, China \\ *These authors contributed equally to this work
}

Correspondence to: Yunyi Liu, email: liuyy1987@jhun.edu.cn

Zhengkai Liao, email: zliao@whu.edu.cn

Jinhua Xu, email: xu5520@gmail.com

Keywords: TNBC, Cu(sal)(phen), cell growth, apoptosis, anti-apoptotic protein

Received: December 20, 2016

Accepted: March 03, 2017

Published: March 13, 2017

Copyright: Fan et al. This is an open-access article distributed under the terms of the Creative Commons Attribution License (CC-BY), which permits unrestricted use, distribution, and reproduction in any medium, provided the original author and source are credited.

\section{ABSTRACT}

In this study, we investigated anti-tumor activity and associated molecular mechanism of action of Salicylate •Phenanthroline Copper (II) Complex in triplenegative breast cancer. Salicylate $\bullet$ Phenanthroline Copper (II) Complex inhibited the growth of four breast cancer cell lines (MCF-7, T47D, MDA-MB-231 and BT-20) and induced apoptosis in a concentration-dependent manner. The effect was more profound in MDA-MB-231 and BT-20 triple-negative breast cancer cell lines. Western blot showed that the expression of the apoptosis-related protein Bcl-2, Bcl-xl and survivin was significantly reduced in MDA-MB-231 after treatment with Salicylate - Phenanthroline Copper (II) Complex. In vivo, Salicylate •Phenanthroline Copper (II) Complex administration significantly attenuated tumor growth of MDA-MB-231 xenografts, and the expression levels of $\mathrm{Bcl}-2, \mathrm{BCl}-\mathrm{xL}$ and survivin were reduced as measured by immunohistochemical staining. These data suggest that Salicylate - Phenanthroline Copper (II) Complex is a promising novel therapeutic drug for triplenegative breast cancer and warrants further study.

\section{INTRODUCTION}

Triple-negative breast cancer (TNBC) accounts for $10 \%$ to $20 \%$ of all breast cancer cases. TNBC is highly aggressive and usually associated with poor prognosis. Unlike other types of breast cancer, TNBC lacks effective targeted therapies since it lacks estrogen receptor, progesterone receptor and HER-2 [1]. Despite significant progress in recent years with the development of potential novel drugs such as PARP inhibitors and bevacizumab, no targeted therapy are currently available for use in the metastatic setting $[2,3]$. Chemotherapy is the standard therapy for TNBC patients[4], and neoadjuvant chemotherapy is often used for treatment of early-stage TNBC, which reduces tumor stage and increases the number of patients suitable for breast-conserving surgery [5]. Although many TNBC patients experience remission, the overall survival (OS) rate is still lower compared to non-TNBC patients [2]. TNBC recurrence typically peaks within three years after treatment, and most patients do not survive beyond five years, although the gap between TNBC and non-TNBC survival decreases after ten years $[1,6]$. When pathologic complete response (pCR) was not achieved in TNBC patients after neoadjuvant chemotherapy, a significantly poorer OS was observed compared to nonTNBC patients with residual disease [7]. Compared with non-platinum-based chemotherapy, platinum-based agents can significantly improve the pCR rate $[8,9]$, although a benefit in OS remains to be seen [10]. Importantly, although most TNBC tumors respond well to chemotherapy initially, they often develop drug resistance [11]. Therefore, there is an urgent need to develop new therapeutic agents for TNBC.

Tumors are characterized with uncontrolled proliferation and a suppression of apoptosis, thus targeting those processes 
may provide effective therapies $[12,13]$. The Bcl-2 family of proteins, including anti-apoptosis factors $\mathrm{Bcl}-\mathrm{xL}$ and Bcl-2 and pro-apoptotic factors Bax, Bik, and Bad, are key apoptosis regulators [14]. Additionally, survivin is a member of the inhibitor of apoptosis proteins (IAP) family that inhibits apoptosis [15]. Both Bcl-2 family proteins and survivin are overexpressed in many types of human cancers, including breast cancer $[16,17]$. Survivin, in particular, is a promising candidate for targeted cancer therapy, as its expression is associated with poor clinical outcome, more aggressive clinicopathologic features, and resistance to radiation and chemotherapy [18].

Salicylic acid and salicylate derivative have been widely used in anti-inflammatory and anti-cancer therapy $[19,20]$. It has been reported that copper (II) complexes of salicylic acid have similar anti-oxidative and anti-tumor activities as superoxide dismutase (SOD) [21]. Specifically, these compounds inhibit the growth of tumor cells, and Sorenson et al., showed that copper salicylic acid had anti-tumor potential in animal models. Treatment led to reduced tumor growth and metastasis, induced tumor cell differentiation, and increased host survival $[22,23]$. Other studies have found that copper salicylic acid chelated with phenanthroline increased its toxicity in tumor cells [24]. Cisplatin-sensitive cell lines, such as breast cancer cells (MCF-7), prostate cancer cells (DU-145), and colon cancer cells (HT-29), and cisplatinresistant cell lines, such as ovarian cancer cells (SKOV-3), were all sensitive to low doses of copper salicylate phenanthroline complexes [21]. Despite these promising anti-cancer effects of $\mathrm{Cu}$ (sal)(phen), its mechanism of action have not been defined.

In this study, we analyzed the effect of $\mathrm{Cu}(\mathrm{sal})$ (phen) on breast cancer cell growth in vitro and anti-tumor activity in vivo. We found that $\mathrm{Cu}(\mathrm{sal})(\mathrm{phen})$ efficiently induces apoptosis of TNBC cells through down-regulation of anti-apoptosis proteins in these cells in vitro and in vivo. Thus, our results suggest that $\mathrm{Cu}(\mathrm{sal})($ phen) is a promising novel therapeutic agent for TNBC.

\section{RESULTS}

\section{$\mathrm{Cu}(\mathrm{sal})($ phen) inhibits the growth of breast cancer cells}

To determine the effect of $\mathrm{Cu}(\mathrm{sal})$ (phen) on growth of breast cancer cells, four breast cancer cell lines (MCF-7, T47D, MDA-MB-231 and BT-20) were treated with increasing concentrations of $\mathrm{Cu}(\mathrm{sal})(\mathrm{phen})(5-25 \mu \mathrm{M})$, and cell growth was assessed by MTS assay. As shown in Figure 1, the growth of all cells was significantly inhibited by $\mathrm{Cu}(\mathrm{sal})(\mathrm{phen})$ treatment compared to the control group $(p<0.01$, Figure 1). There was a dose-dependent effect of the compound; the extent of inhibition was positively correlated with increasing $\mathrm{Cu}$ (sal)(phen) concentration. When the $\mathrm{Cu}(\mathrm{sal})(\mathrm{phen})$ concentration reached $25 \mu \mathrm{M}$, cell growth was almost completely inhibited. In addition, the effect was more profound in MDA-MB-231 and BT-20 TNBC cell lines compared with MCF-7 and T47D nonTNBC cell lines (Figure 1).

\section{$\mathrm{Cu}(\mathrm{sal})(\mathrm{phen})$ induces apoptosis of breast cancer cells}

To determine the involvement of apoptosis in the $\mathrm{Cu}$ (sal)(phen) activity, all breast cancer cell lines MCF-7, T47D, MDA-MB-231 and BT-20 were treated with 5,10 and $25 \mu \mathrm{M}$ of $\mathrm{Cu}(\mathrm{sal})(\mathrm{phen})$ for $24 \mathrm{hrs}$, and then apoptosis was analyzed by flow cytometry after Annexin V/PI double staining. The proportion of apoptotic cells upon $\mathrm{Cu}(\mathrm{sal})($ phen) treatment increased in a dosedependent manner (Figure 2A). MDA-MB-231 TNBC cells showed more cells in early apoptosis compared with MCF-7 non-TNBC cells. Overall, the MDA-MB-231 and BT-20 TNBC cells were more sensitive to $\mathrm{Cu}$ (sal)(phen) treatment compared to MCF-7 and T47D non-TNBC cells (Figure 2B). Treatment with $25 \mu \mathrm{M} \mathrm{Cu}$ (sal)(phen) for $24 \mathrm{hrs}$ resulted in more than $80 \%$ of TNBC cells (MDAMB-231 and BT-20) undergoing apoptosis, but only $40 \%$ of non-TNBC cells (MCF-7 and T47D). These results indicated that $\mathrm{Cu}(\mathrm{sal})($ phen) induced potent apoptotic activity in TNBC cells.

\section{$\mathrm{Cu}(\mathrm{sal})(\mathrm{phen})$ induces apoptosis through down- regulation of anti-apoptosis proteins in breast cancer cells}

To understand the molecular mechanism by which $\mathrm{Cu}$ (sal)(phen) induces apoptosis of breast cancer cells, we analyzed the expression levels of several apoptosisrelated proteins after drug treatment of MCF-7 and MDAMB-231 cells by Western blot. As shown in Figure 3, the basal expression levels of $\mathrm{Bcl}-2, \mathrm{Bcl}-\mathrm{xL}$ and survivin were much higher in the MDA-MB-231 TNBC cells than in non-TNBC MCF-7 cells. The expression levels of Bcl-2 and Bcl-xL decreased significantly in MDAMB-231 cells after drug treatment (Figure 3A). The expression level of survivin was also reduced in MCF7 and MDA-MB-231 cells treated with $25 \mu \mathrm{M} \mathrm{Cu}(\mathrm{sal})$ (phen) (Figure 3A). Quantification of the Western blot results showed that there was a $\sim 80 \%$ decrease in survivin in treated MDA-MB-231 cells compared with a $\sim 43 \%$ decrease in MCF-7 cells (Figure 3B). In addition to the reduction of Bcl-xL expression in MDA-MB-231 cells, we also observed a shift of the band, likely corresponding to a change in phosphorylation state of the protein [25]. Indeed, phosphorylation level of Bcl-xL was dramatically increased in MDA-MB-231 cells after the treatment (Figure 3A, 3B). These findings suggest that $\mathrm{Cu}(\mathrm{sal})$ (phen) induces apoptosis through down-regulation of anti-apoptosis proteins in breast cancer cells, especially TNBC cells. Moreover, we analyzed the expression of 
cleaved PARP, which is a marker of activation of apoptosis pathways. We found that the expression of cleaved PARP was increased in both MCF-7 and MDA-MB-231 cell lines after $\mathrm{Cu}(\mathrm{sal})$ (phen) treatment (Figure 3A, 3B).

\section{$\mathrm{Cu}(\mathrm{sal})(\mathrm{phen})$ inhibits tumor growth in vivo}

Breast tumor xenografts were generated in nude mice injected with cultured MDA-MB-231 cells, and then tumor blocks were seeded for second-generation tumor formation. Compared with directly injecting cultured cells, we found that the method of tissue block insertion has many technological advantages, such as higher tumor formation rates, faster tumor growth and more uniform tumor size. Figure 4A shows the tumor growth curves of the two groups; the tumor volume of drug-treated group was significantly reduced compared to the control group at 10 days after drug treatment. Examination of the histopathology of the tumors revealed obvious necrotic areas in tumors from the drug-treated group that were not observed in the control tumors (Figure 4C). Consistent with the drug being well-tolerated, the weight of treated animals was not statistically different from the control animals (Figure 4B). Collectively, these data indicate that, at the concentration used, $\mathrm{Cu}(\mathrm{sal})($ phen) inhibits tumor growth and is well tolerated in vivo.

\section{$\mathrm{Cu}(\mathrm{sal})(\mathrm{phen})$ down regulates anti-apoptosis proteins in vivo}

We next explored the potential mechanism underlying the anti-tumor activity of $\mathrm{Cu}(\mathrm{sal})($ phen) in vivo by examining the expression levels of the apoptotic proteins Bcl-2, Bcl-xL, survivin and proliferation marker Ki-67 by immunohistochemical staining of the tumors and semiquantitative image analysis. The expression levels of Bcl-2, $\mathrm{Bcl}-\mathrm{xL}$, survivin and $\mathrm{Ki}-67$ were all reduced in $\mathrm{Cu}(\mathrm{sal})(\mathrm{phen})-$ treated tumors compared to the tumors from the control mice (Figure 5A). The average of integrated optical density (IOD) values of $\mathrm{Bcl}-2, \mathrm{Bcl}-\mathrm{xL}$, survivin and $\mathrm{Ki}-67$ in the $\mathrm{Cu}(\mathrm{sal})$ (phen) treated group was significantly lower than those in the control group (Figure 5B). These results demonstrated that $\mathrm{Cu}$ (sal)(phen) down-regulates the expression levels of Bcl-2, Bcl-xL, survivin and Ki-67 in tumors.

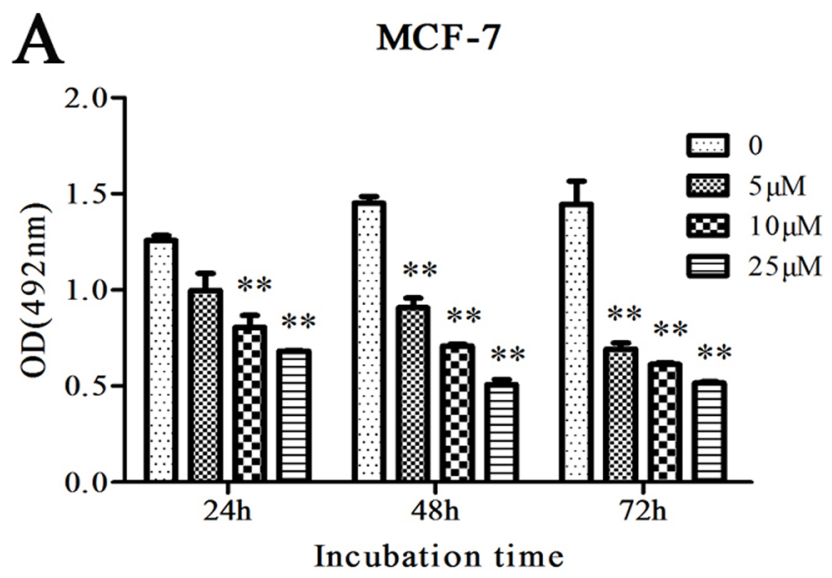

B

T47D

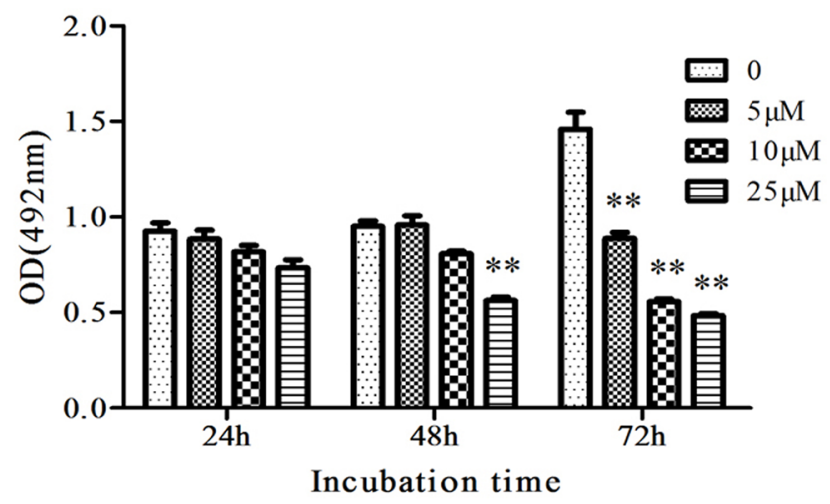

C

$\mathrm{D}$

MDA-MB-231

BT-20
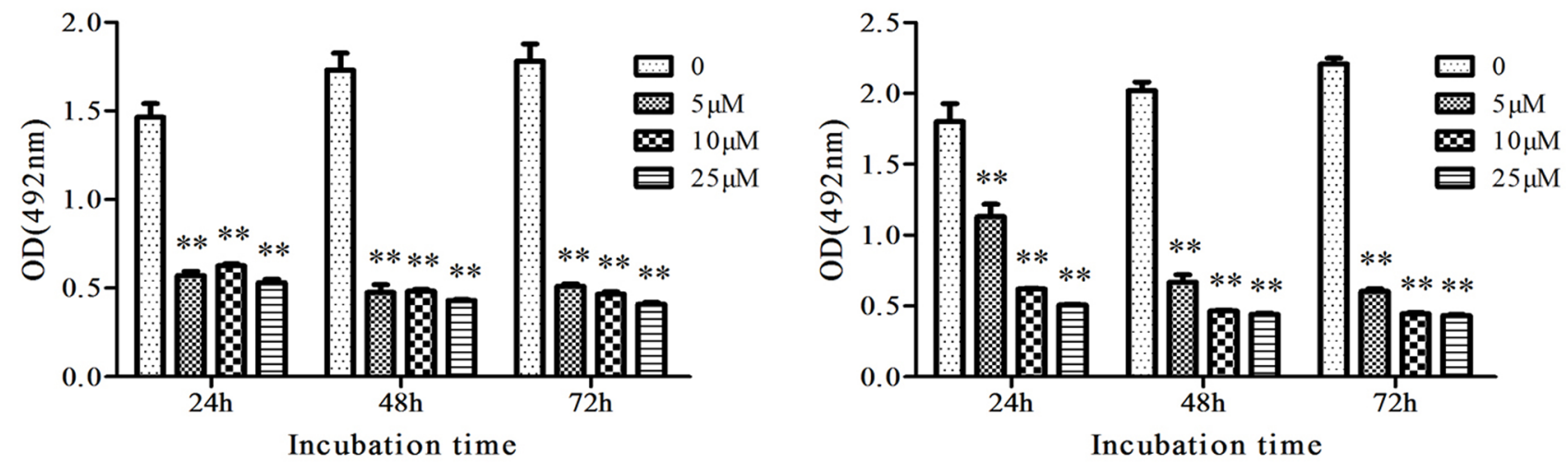

Figure 1: Cu(sal)(phen) inhibits growth of breast cancer cells. MCF-7(A), T47D(B), MDA-MB-231(C) and BT-20(D) were treated with $0-25 \mu \mathrm{M}$ of $\mathrm{Cu}(\mathrm{sal})(\mathrm{phen})$, and cell growth was measured with the MTS assay at indicated time periods. Results are represented as the average of two independent experiments with triplicates. Bar represents mean \pm SD. $* * p<0.01$. 


\section{DISCUSSION}

It has been shown that $\mathrm{Cu}(\mathrm{sal})($ phen) effectively inhibits growth of cisplatin-sensitive cell lines, as well as cisplatin-resistant cancer cell line [21]. However, the precise molecular mechanism of action has not been well established. In the current study, we demonstrated that $\mathrm{Cu}$ (sal)(phen) efficiently induced apoptosis of breast cancer cells, especially TNBC cells. Furthermore, $\mathrm{Cu}(\mathrm{sal})$ (phen) inhibited TNBC tumor growth in a xenograft model and induced apoptosis through down-regulating expression of anti-apoptosis proteins $\mathrm{Bcl}-2, \mathrm{Bcl}-\mathrm{xL}$ and survivin both in vitro and in vivo.

In contrast to the observation that $\mathrm{Bcl}-2 / \mathrm{Bcl}-\mathrm{xL}$ were primarily expressed in ER-positive breast cancer cells
[26], we found that MDA-MB-231 TNBC cells exhibited much higher level of Bcl-2 and Bcl-xL compared to ERpositive MCF-7 breast cancer cells. Upon $\mathrm{Cu}(\mathrm{sal})($ phen) treatment, the protein levels of Bcl-2 and Bcl-xL were dramatically down-regulated in MDA-MB-231 cells. In addition, the level of the phosphorylated $\mathrm{Bcl}-\mathrm{xL}$ was significantly increased in MDA-MB-231 cells. Bcl-xL is phosphorylated at the activation loop on the Ser62 by JNK, which modulates the Bax/Bcl-xL interactions and inhibits Bcl-xL's anti-apoptotic activity [25, 27]. These data suggest that multiple mechanisms are likely to be involved in the induction of apoptosis by $\mathrm{Cu}(\mathrm{sal})(\mathrm{phen})$.

Survivin primarily inhibits apoptosis through suppressing activation of caspase-3 and caspase-7, interfering with caspase-9 activity, and blocking the
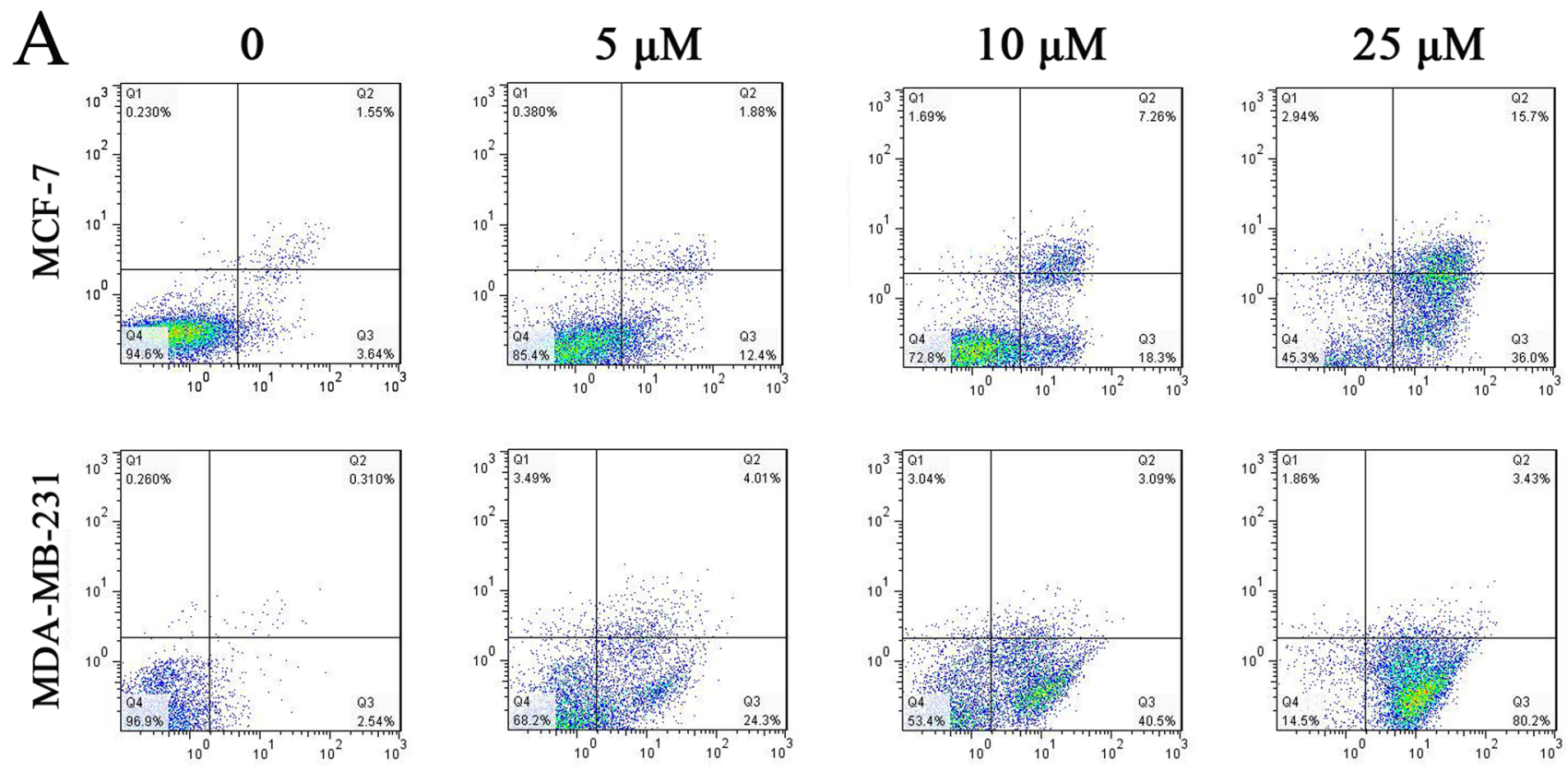

B

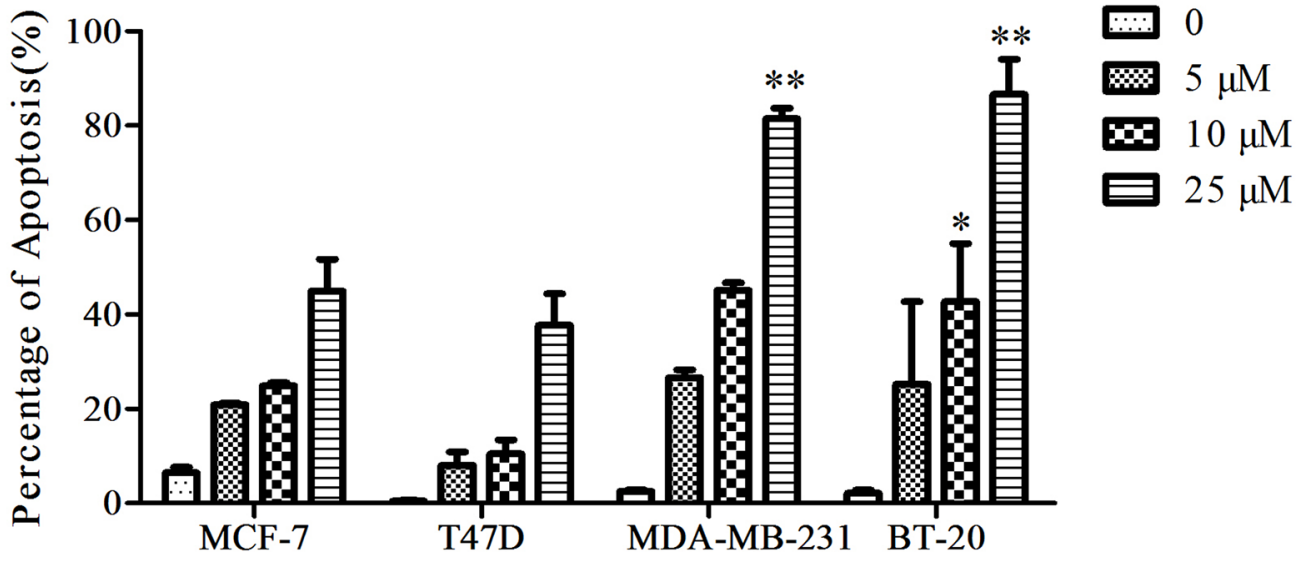

Figure 2: $\mathbf{C u}(\mathbf{s a l})($ phen) induces apoptosis of breast cancer cells. MCF-7, T47D, MDA-MB-231 and BT-20 were treated with $0,5,10$ and $25 \mu \mathrm{M}$ of $\mathrm{Cu}(\mathrm{sal})(\mathrm{phen})$ for $24 \mathrm{hrs}$, and apoptosis was assessed with the flow cytometry after Annexin V/PI double staining. (A). Representative flow cytometry histograms of MCF-7 cells and MDA-MB-231 cells treated with Cu(sal)(phen) or vehicle (DMSO). (B). Summary of flow cytometry analyses. Results are represented as the average of two independent experiments. Bars represent mean \pm SD. $* p<0.05, * * p<0.01$. 

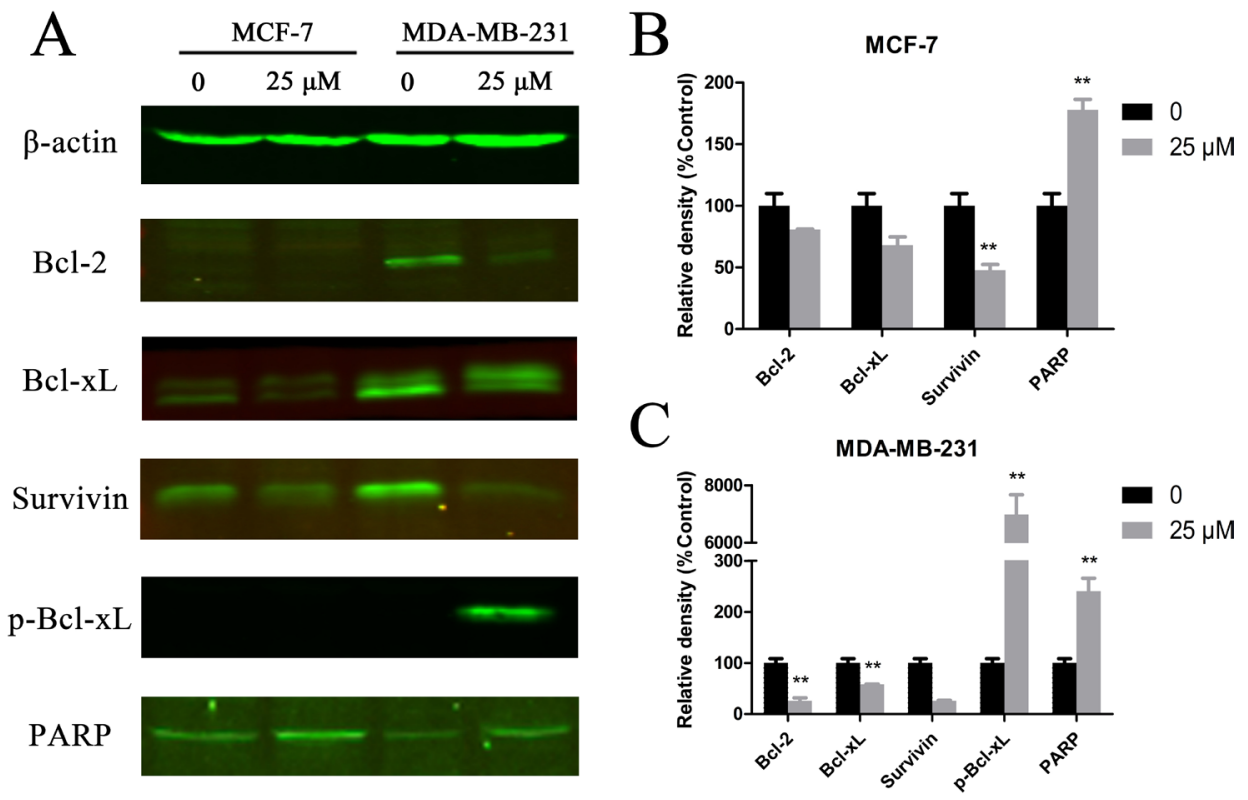

Figure 3: $\mathrm{Cu}(\mathrm{sal})($ phen) treatment down-regulates expression of anti-apoptotic proteins. MCF-7 and MDA-MB-231 cells were treated with $25 \mu \mathrm{M}$ of $\mathrm{Cu}(\mathrm{sal})$ (phen) or DMSO as a control and expression of anti-apoptotic proteins was analyzed with Western blot analysis. Actin was used as a loading control. (A). Representative Western blot images of Bcl-2, Bcl-xL, phospho-Bcl-xL, survivin and PARP in MCF-7 and MDA-MB-231 cells. (B). Quantitative analysis of Western blot images from MCF-7 cells. The densities of target bands were scanned, and values were normalized with actin. (C). Quantitative analysis of Western blot images of MDA-MB-231. The densities of target bands were scanned, and values were normalized with actin. Results are represented as the average of two independent experiments. Bars represent mean $\pm \mathrm{SD}$. ${ }^{*} p<0.05,{ }^{*} p<0.01$

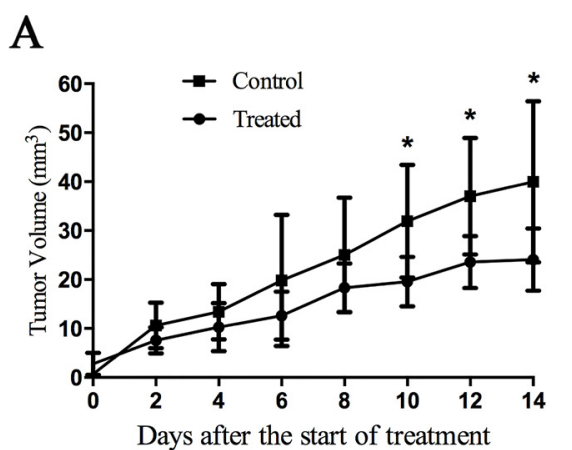

$\mathrm{C}$

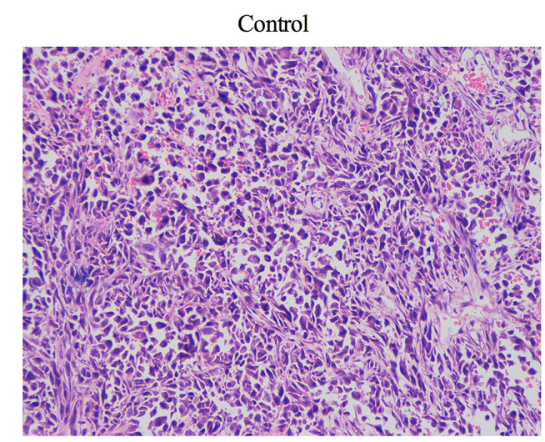

B
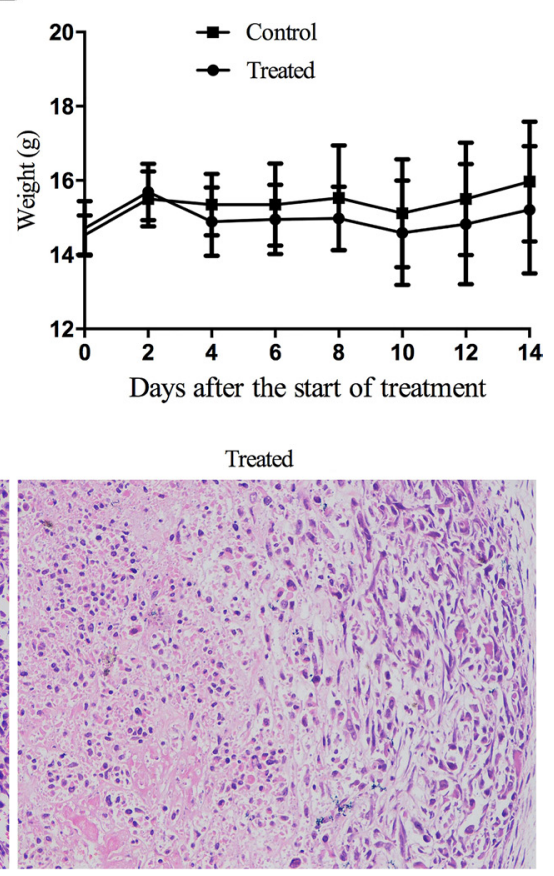

Figure 4: Cu(sal)(phen) suppresses tumor growth in vivo. 1-mm $\mathrm{m}^{3}$ tumor block from MDA-MB-231 cells innoculated nude mice was seeded into the mammary fat pad of BALB/c-nu female mice. The mice were injected intraperitoneally (i.p.) every 2 days with $0.1 \mathrm{ml}$ of DMSO or $\mathrm{Cu}(\mathrm{sal})(\mathrm{phen})(0.5 \mathrm{mg} / \mathrm{ml})$. The tumor size and the body weight were measured every other day throughout the experiments. After 14 days of treatment, the mice were euthanized, the tumors were fixed, sectioned and stained with hematoxylin and eosin (H\&E). (A). Tumor volume for tumor-bearing mice is shown with mean per group $(n=8)$. ${ }^{*} p<0.05$ between the treated and control groups. (B). There was no statistical difference of mean body weight between the treated and control groups. (C). H\&E staining of tumor specimens from the mice injected with $\mathrm{Cu}(\mathrm{sal})(\mathrm{phen})$ or DMSO. Magnification, X200. 
downstream effectors of apoptosis pathways [28]. Survivin is often overexpressed in breast cancer [29], and is associated with less apoptosis [30], poor overall survival [31], and resistance to neoadjuvant chemotherapy [32]. Several therapeutic approaches targeting survivin have been tested, including inhibition of survivin transcription, post-translational inhibition of survivin, vaccines against survivin, and gene therapy approaches such as gene editing [33]. In this study, we found that the expression of survivin protein was dramatically reduced by $\mathrm{Cu}(\mathrm{sal})$ (phen) treatment in breast cancer cells, especially in TNBC cells, suggesting that $\mathrm{Cu}(\mathrm{sal})(\mathrm{phen})$ may provide a promising approach to target survivin expression.

In this study, we also found that $\mathrm{Cu}$ (sal)(phen) treatment attenuated tumor growth in vivo. Similar to what was observed in vitro, the expression levels of Bcl-2, $\mathrm{Bcl}-\mathrm{xL}$ and survivin proteins were down-regulated in tumor tissue from drug-treated animals as detected by
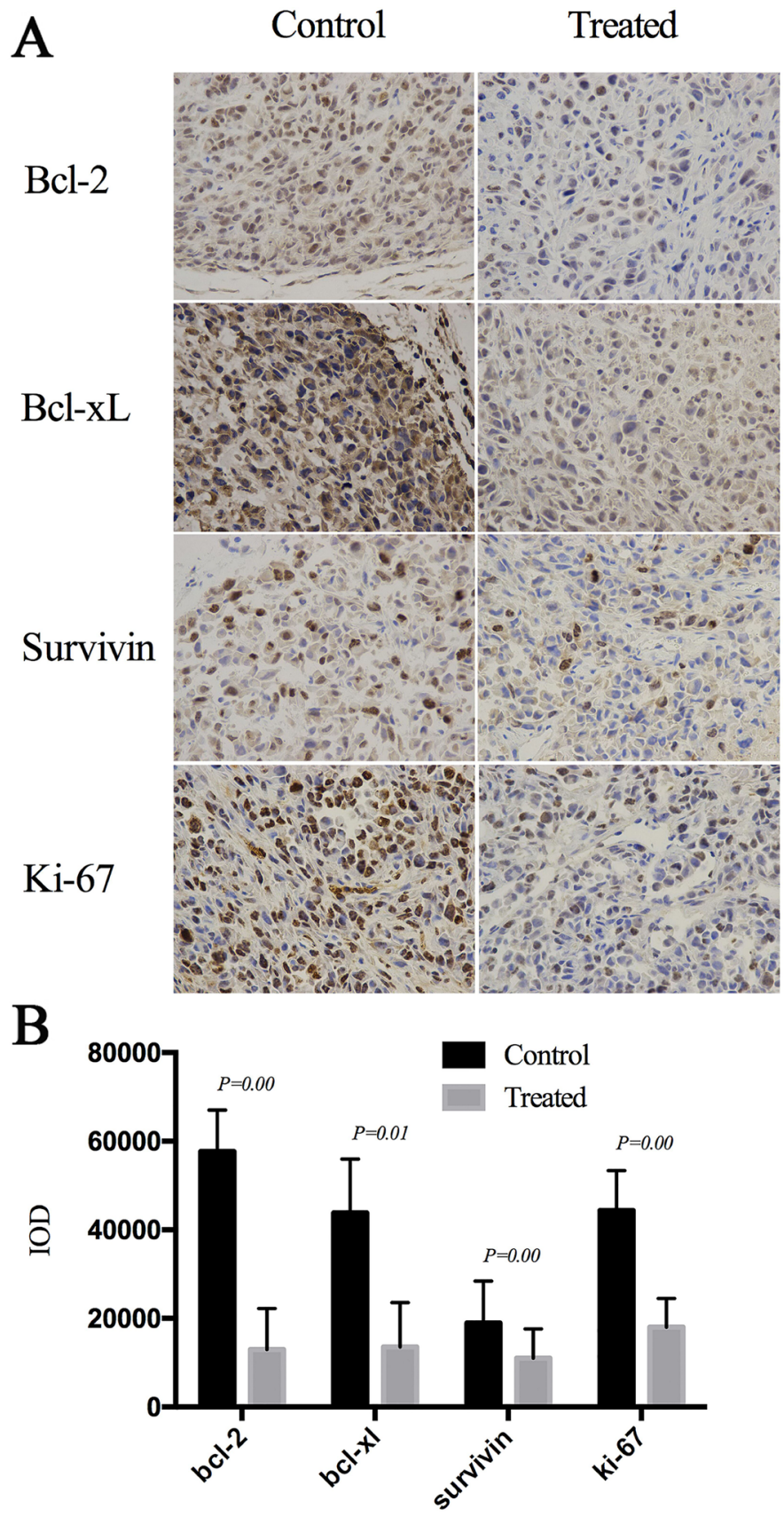

Figure 5: $\mathrm{Cu}(\mathrm{sal})(\mathrm{phen})$ down-regulates expression of anti-apoptotic and proliferation-related proteins in xenografted tumors. Formalin-fixed, paraffin-embedded sections were stained with antibodies against Bcl-2, Bcl-xL, survivin and Ki-67. Images were taken and the integrated optical density (IOD, $n=24$ for each protein) was measured by image-pro plus 6.0 software. (A). Expression of Bcl-2, Bcl-xL, Survivin and Ki-67 in the treated tumor and control analyzed with Immunohistochemistry. (B). Results of semi-quantitative image analysis of immunohistochemistry. The expression levels of all four proteins in the treated and control groups. 
immunohistochemistry. These findings suggest that apoptosis induced by $\mathrm{Cu}(\mathrm{sal})$ (phen) is likely to be responsible for its anti-tumor activity. Interestingly, Ki67, a proliferation marker of tumor [34] and a prognosis marker for breast cancer, was also down-regulated in tumors in animals treated with $\mathrm{Cu}(\mathrm{sal})$ (phen), suggesting that $\mathrm{Cu}$ (sal) (phen) treatment also suppressed tumor cell proliferation.

Although targeted therapies have long been sought for TNBC, there has been limited success. Interestingly, we found that the growth inhibitory activity of $\mathrm{Cu}$ (sal) (phen) was more profound in TNBC cell lines, compared to ER-positive MCF-7 cells. One of the concerns for developing $\mathrm{Cu}(\mathrm{sal})$ (phen) as a therapeutic agent for TNBC treatment is toxicity. Although our in vivo experiment showed that mice well tolerated the dose that effectively suppressed the tumor growth, additional experiments are required in order to further develop it into an effective, less toxic, novel therapeutic agent for human TNBC.

\section{MATERIALS AND METHODS}

\section{Chemicals}

$\mathrm{Cu}$ (sal)(phen) was synthesized by Dinglong Chemicals (Wuhan, Hubei, China), with a two-step reaction. In the first step, $9.7 \mathrm{~g}$ of copper hydroxide $\mathrm{Cu}(\mathrm{OH})_{2}$ and $56.2 \mathrm{~g}$ of salicylic acid were refluxed in $600 \mathrm{ml}$ pure ethanol for $8 \mathrm{hrs}$. Upon cooling to room temperature, a yellowish precipitate was collected by filtration. The solid product was further purified by ethanol for three times, and dried in vacuum at $60^{\circ} \mathrm{C}$ to generate $\mathrm{Cu}(\mathrm{sal})_{2}\left(\mathrm{H}_{2} \mathrm{O}\right)_{2}$. In the second step , $3.8 \mathrm{~g}$ of the product from the step 1 and $4.3 \mathrm{~g}$ of 1,10-phenanthroline were refluxed in $350 \mathrm{ml}$ pure ethanol for $4 \mathrm{hrs}$, to generate a greenish mixture. After cooled to room temperature, the green precipitate was collected by filtration, and washed by hot ethanol for three times. The final product $\mathrm{Cu}(\mathrm{sal})$ (phen) was dried at $75^{\circ} \mathrm{C}$ in a vacuum for $8 \mathrm{hrs}$. $5 \mathrm{mM}$ stock solution was made by dissolving $\mathrm{Cu}$ (sal)(phen) in dimethyl sulfoxide (DMSO) and diluted when used. The solvent DMSO was used as mock control.

\section{Cell lines}

MCF-7, T47D, MDA-MB-231 and BT-20 cell lines were obtained from the American Type Culture Collection (Rockville, MD, USA). MCF-7 and T47D cells were cultured in DMEM (Fisher Scientific, Hanover Park, IL). MDA-MB-231 and BT-20 cells were maintained in RPMI 1640 (Invitrogen, Grand Island, NY, USA). The media were supplemented with $10 \%$ FBS and $1 \%$ penicillin/streptomycin. Cell lines under 20 passages were used for all experiments.

\section{Cell growth assays}

Cell growth was analyzed with the MTS assay using CellTiter 96 ${ }^{\circledR}$ AQueous One Solution Cell Proliferation Assay (Promega, WI, USA) according to the manufacture recommendation. Briefly, cells were seeded in 96-well culture plates. Following treatment with $\mathrm{Cu}(\mathrm{sal})($ phen) or DMSO as a control, cell viability was assessed by adding 3-(4,5-dimethylthiazol-2-yl)-5-(3-carboxymethoxyphenyl)2-(4-sulfophenyl)-2H-tetrazolium (MTS) to the culture medium and incubated for $4 \mathrm{hrs}$ at $37^{\circ} \mathrm{C}$. The optical density was measured at $490 \mathrm{~nm}$ using a Synergy 2 plate reader (Biotek, VT, USA).

\section{Apoptosis assay}

Apoptosis was assessed quantitatively using Annexin V (BD Biosciences) and propidium iodide (PI) double staining. After treatment, cells were harvested by trypsinization, stained with Annexin V-FITC, and 50 $\mu \mathrm{g} / \mathrm{mL}$ of PI solution, then immediately analyzed by the Coulter Epics XL Flow Cytometer (Beckman, USA). Experiments were performed in triplicate, and a total of 10,000 cells were analyzed in each experiment.

\section{Western blotting}

Total cell lysate was extracted in the RIPA buffer containing protease inhibitor cocktail as described previously [35]. $25 \mu \mathrm{g}$ of lysate from each cell line was separated using SDS-PAGE gel and transferred to Immobilon P membrane (Millipore). Blots were probed with the following antibodies: anti-Bcl-2 antibody (2870, Cell Signaling, USA), anti-Bcl-xL (2764, Cell Signaling, USA), anti-phospho-Bcl-xL (sc-101644, Santa Cruz, USA), anti-survivin (2808, Cell Signaling, USA) and anti-actin monoclonal antibody (Sigma, USA) in blocking buffer (Li-Cor, NB, USA). Then the membranes were incubated with IRDye secondary antibodies (Licor, NB, USA). The membranes were scanned and the images were captured with Odyssey SA (Licor, NB, USA). Images were analyzed and quantified using ImageStudio software.

\section{Xenograft transplantation assays}

All animal studies were performed in accordance with the Novartis Institutes for BioMedical Research (NIBR) Animal Care and Use Committee protocols and regulations approved by Institutional Animal Care and Use Committee of Wuhan University. Four-week-old BALB/c-nu female mice were purchased from Hunan SJA Laboratory Animal Co. Ltd. (Hunan, China), and tumors were generated by subcutaneous injection of $5 \times 10^{6}$ MDA-MB-231 cells as described previously [36]. When the diameters of the tumors reached $1 \mathrm{~cm}$, the tumors were removed and cut into $1-\mathrm{mm}^{3}$ tumor blocks. The tumor blocks were seeded for the second-generation tumors. After implantation in subcutaneous tissue, the mice were divided randomly into two groups of eight mice each. The tumor diameter was measured every other day, and tumor volume was calculated as described previously [37]. When the diameter of the tumor was greater than $3 \mathrm{~mm}$, animals were 
treated with either vehicle (DMSO) or $\mathrm{Cu}(\mathrm{sal})$ (phen) every other day by intraperitoneally (i.p.) injection with $100 \mu$ l of DMSO or $0.5 \mathrm{mg} / \mathrm{ml} \mathrm{Cu}(\mathrm{sal})(\mathrm{phen})$ in the same volume of DMSO, as determined by a pilot experiment. Animal body weights were monitored every other day. After 14 days of treatment, the mice were euthanized, the tumors were fixed in paraformaldehyde, embedded in paraffin, sectioned and stained with hematoxylin and eosin (H\&E).

\section{Immunohistochemistry assays}

Immunohistochemistry was performed on formalinfixed, paraffin-embedded sections with the following antibodies: anti-Bcl-2 (ab28819,Abcam), anti-Bcl-xL (ab180849, Abcam), anti-survivin (ab8228, Abcam) and antiKi-67 (ab6526, Abcam). Antigen retrieval was carried out in boiling EDTA buffer. The biotinylated secondary antibody was added to the sections. Finally, tissue sections were stained with DAB solution. Three areas of each tumor tissue section were randomly selected, and images were taken at a 400-fold magnification (Olympus BX51). Positive cells on three sections for each tumor were quantified. The integrated optical density (IOD, $n=24$ ) was measured by Image-pro plus 6.0 software.

\section{Statistical analysis}

All experiments were performed at least twice, and statistical analyses were performed using a one-way ANOVA with a Student's $t$-test post-test, unless noted otherwise. For quantification, means are shown with standard deviation (SD). For immunohistochemistry analysis, the comparison between the experimental group and the control group was assessed by $t$-test and performed with SPSS 16.0 software. A value of $p<0.05$ was considered statistically significant.

\section{Abbreviations}

$\mathrm{Cu}(\mathrm{sal})($ phen): Salicylate $\bullet$ Phenanthroline Copper (II) Complex; DMSO: Dimethyl sulfoxide; FBS: fetal bovine serum; H\&E: hematoxylin and eosin; HER-2: human epidermal growth factor receptor 2; IAP: inhibitor of apoptosis proteins; IOD: integrated optical density; MTS:3(4,5-dimethylthiazol-2-yl)-5-(3-carboxymethoxyphenyl)-2(4-sulfophenyl)-2H-tetrazolium; OS: overall survival; PARP: poly ADP-ribose polymerase; pCR: pathologic complete response; PI: propidium iodide; SOD: superoxide dismutase; TNBC: Triple-negative breast cancer.

\section{Authors' contributions}

LF, MT, YL, YD and KL conducted the experiments. YL and KL participated in its design and coordination, and helped to analyze the data and draft the manuscript. JX conceived and designed the study, analyzed the data and wrote the manuscript. All authors read and approved the final manuscript.

\section{ACKNOWLEDGMENTS}

We thank Dr. Yuhua Tong for technical advices and Dinglong Chemicals for synthesis of $\mathrm{Cu}(\mathrm{sal})$ (phen). We thank Dr. Kathleen H. Goss (University of Chicago Medicine Comprehensive Cancer Center) and Mrs. Elisabeth W. Sveen for critical reading of the manuscript.

\section{CONFLICTS OF INTEREST}

The authors declare that they have no conflicts of interest.

\section{GRANT SUPPORT}

Startup fund from Jianghan Univesity to J. Xu. Huanghe Talented Scholar grant of Wuhan City to J. $\mathrm{Xu}$. National Natural Science Foundation of China grant (81602642) to Y. Liu. J. Xu is a Chutian Scholar of Department of Education, Hubei Province.

\section{REFERENCES}

1. Foulkes WD, Smith IE, Reis-Filho JS. Triple-negative breast cancer. The New England journal of medicine. 2010; 363:1938-1948.

2. Palma G, Frasci G, Chirico A, Esposito E, Siani C, Saturnino C, Arra C, Ciliberto G, Giordano A, D'Aiuto M. Triple negative breast cancer: looking for the missing link between biology and treatments. Oncotarget. 2015; 6:26560-26574. doi: 10.18632/oncotarget.5306.

3. Sharma P. Biology and Management of Patients With Triple-Negative Breast Cancer. The oncologist. 2016; 21:1050-1062.

4. Bianchini G, Balko JM, Mayer IA, Sanders ME, Gianni L. Triple-negative breast cancer: challenges and opportunities of a heterogeneous disease. Nature reviews Clinical oncology. 2016.

5. Wolmark N, Wang J, Mamounas E, Bryant J, Fisher B. Preoperative chemotherapy in patients with operable breast cancer: nine-year results from National Surgical Adjuvant Breast and Bowel Project B-18. Journal of the National Cancer Institute Monographs. 2001:96-102.

6. Dent R, Trudeau M, Pritchard KI, Hanna WM, Kahn HK, Sawka CA, Lickley LA, Rawlinson E, Sun P, Narod SA. Triple-negative breast cancer: clinical features and patterns of recurrence. Clinical cancer research. 2007; 13:4429-4434.

7. Liedtke C, Mazouni C, Hess KR, André F, Tordai A, Mejia JA, Symmans WF, Gonzalez-Angulo AM, Hennessy B, Green M, Cristofanilli M, Hortobagyi GN, Pusztai L. Response to neoadjuvant therapy and long-term survival in patients with triple-negative breast cancer. Journal of clinical oncology. 2008; 26:1275-1281. 
8. von Minckwitz G, Schneeweiss A, Loibl S, Salat C, Denkert C, Rezai M, Blohmer JU, Jackisch C, Paepke S, Gerber B, Zahm DM, Kümmel S, Eidtmann H, et al. Neoadjuvant carboplatin in patients with triple-negative and HER2-positive early breast cancer (GeparSixto; GBG 66): a randomised phase 2 trial. The Lancet Oncology. 2014; 15:747-756.

9. Petrelli F, Coinu A, Borgonovo K, Cabiddu M, Ghilardi M, Lonati V, Barni S. The value of platinum agents as neoadjuvant chemotherapy in triple-negative breast cancers: a systematic review and meta-analysis. Breast cancer research and treatment. 2014; 144:223-232.

10. Loibl S, Denkert C, von Minckwitz G. Neoadjuvant treatment of breast cancer--Clinical and research perspective. Breast. 2015; 24:S73-77.

11. Carey L, Winer E, Viale G, Cameron D, Gianni L. Triplenegative breast cancer: disease entity or title of convenience? Nature reviews Clinical oncology. 2010; 7:683-692.

12. Hanahan D, Weinberg RA. The hallmarks of cancer. Cell. 2000; 100:57-70.

13. Evan GI, Vousden KH. Proliferation, cell cycle and apoptosis in cancer. Nature. 2001; 411:342-348.

14. Kirkin V, Joos S, Zörnig M. The role of Bcl-2 family members in tumorigenesis. Biochimica et Biophysica Acta (BBA)-Molecular Cell Research. 2004; 1644:229-249.

15. Deveraux QL, Reed JC. IAP family proteins - suppressors of apoptosis. Genes \& development. 1999; 13:239-252.

16. Mita AC, Mita MM, Nawrocki ST, Giles FJ. Survivin: key regulator of mitosis and apoptosis and novel target for cancer therapeutics. Clinical Cancer Research. 2008; 14:5000-5005.

17. Sohn DM, Kim SY, Baek MJ, Lim CW, Lee MH, Cho MS, Kim TY. Expression of survivin and clinical correlation in patients with breast cancer. Biomedicine \& pharmacotherapy. 2006; 60:289-292.

18. Necochea-Campion R, Chen CS, Mirshahidi S, Howard FD, Wall NR. Clinico-pathologic relevance of Survivin splice variant expression in cancer. Cancer letters. 2013; 339:167-174.

19. Thun MJ, Henley SJ, Patrono C. Nonsteroidal antiinflammatory drugs as anticancer agents: mechanistic, pharmacologic, and clinical issues. Journal of the National Cancer Institute. 2002; 94:252-266.

20. Cuzick J, Otto F, Baron JA, Brown PH, Burn J, Greenwald P, Jankowski J, La Vecchia C, Meyskens F, Senn HJ. Aspirin and non-steroidal anti-inflammatory drugs for cancer prevention: an international consensus statement. The lancet oncology. 2009; 10:501-507.

21. O'Connor M, Kellett A, McCann M, Rosair G, McNamara M, Howe O, Creaven BS, McClean S, Kia AF, O'Shea D, Devereux M. Copper(II) complexes of salicylic acid combining superoxide dismutase mimetic properties with DNA binding and cleaving capabilities display promising chemotherapeutic potential with fast acting in vitro cytotoxicity against cisplatin sensitive and resistant cancer cell lines. Journal of medicinal chemistry. 2012; 55:1957-1968.
22. Sorenson JR. Inflammatory diseases and copper. Journal of the Royal Society of Medicine. 1984, 77:256.

23. Sorenson JR, Wangila GW. Co-treatment with copper compounds dramatically decreases toxicities observed with cisplatin cancer therapy and the anticancer efficacy of some copper chelates supports the conclusion that copper chelate therapy may be markedly more effective and less toxic than cisplatin therapy. Current medicinal chemistry. 2007; 14:1499-1503.

24. Devereux M, O'Shea D, O'Connor M, Grehan H, Connor G, McCann M, Rosair G, Lyng F, Kellett A, Walsh M. Synthesis, catalase, superoxide dismutase and antitumour activities of copper (II) carboxylate complexes incorporating benzimidazole, 1, 10-phenanthroline and bipyridine ligands: X-ray crystal structures of [Cu (BZA) 2 (bipy)(H $2 \mathrm{O})],[\mathrm{Cu}(\mathrm{SalH}) 2(\mathrm{BZDH}) 2]$ and $[\mathrm{Cu}(\mathrm{CH} 3 \mathrm{COO}) 2$ (5, 6-DMBZDH) 2](SalH 2= salicylic acid; $\mathrm{BZAH}=$ benzoic acid; $\mathrm{BZDH}=$ benzimidazole and 5, 6-DMBZDH $=5$, 6-dimethylbenzimidazole). Polyhedron. 2007; 26:4073-4084.

25. Basu A, Haldar S. Identification of a novel Bcl-xL phosphorylation site regulating the sensitivity of taxol- or 2-methoxyestradiol-induced apoptosis. FEBS letters. 2003; 538:41-47.

26. Gee JM, Robertson JF, Ellis IO, Willsher P, McClelland RA, Hoyle HB, Kyme SR, Finlay P, Blamey RW, Nicholson RI. Immunocytochemical localization of BCL-2 protein in human breast cancers and its relationship to a series of prognostic markers and response to endocrine therapy. International journal of cancer. 1994; 59:619-628.

27. Upreti M, Galitovskaya EN, Chu R, Tackett AJ, Terrano DT, Granell S, Chambers TC. Identification of the major phosphorylation site in Bcl-xL induced by microtubule inhibitors and analysis of its functional significance. The Journal of biological chemistry. 2008; 283:35517-35525.

28. Altieri DC. Survivin, cancer networks and pathway-directed drug discovery. Nature reviews Cancer. 2008; 8:61-70.

29. Lv YG, Yu F, Yao Q, Chen JH, Wang L. The role of survivin in diagnosis, prognosis and treatment of breast cancer. Journal of thoracic disease. 2010; 2:100-110.

30. Tanaka K, Iwamoto S, Gon G, Nohara T, Iwamoto M, Tanigawa N. Expression of survivin and its relationship to loss of apoptosis in breast carcinomas. Clinical cancer research : an official journal of the American Association for Cancer Research. 2000; 6:127-134.

31. Song J, Su H, Zhou YY, Guo LL. Prognostic value of survivin expression in breast cancer patients: a metaanalysis. Tumour biology : the journal of the International Society for Oncodevelopmental Biology and Medicine. 2013; 34:2053-2062.

32. Hamy AS, Bieche I, Lehmann-Che J, Scott V, Bertheau $\mathrm{P}$, Guinebretière JM, Matthieu MC, Sigal-Zafrani B, Tembo O, Marty M, Asselain B, Spyratos F, de Cremoux P. BIRC5 (survivin): a pejorative prognostic marker in stage II/III breast cancer with no response to neoadjuvant chemotherapy. Breast cancer research and treatment. 2016; 159:499-511. 
33. Chen X, Duan N, Zhang C, Zhang W. Survivin, Tumorigenesis. Molecular Mechanisms and Therapeutic Strategies. Journal of Cancer. 2016; 7:314-323.

34. Urruticoechea A, Smith IE, Dowsett M. Proliferation marker Ki-67 in early breast cancer. Journal of clinical oncology. 2005; 23:7212-7220.

35. Xu J, Chen Y, Huo D, Khramtsov A, Khramtsova G, Zhang C, Goss KH, Olopade OI. beta-catenin regulates c-Myc and CDKN1A expression in breast cancer cells. Molecular carcinogenesis. 2016; 55:431-439.
36. Xu J, Prosperi JR, Choudhury N, Olopade OI, Goss KH. $\beta$-Catenin is required for the tumorigenic behavior of triplenegative breast cancer cells. PloS one. 2015; 10:e117097.

37. Prosperi JR, Khramtsov AI, Khramtsova GF, Goss KH. Apc mutation enhances PyMT-induced mammary tumorigenesis. PloS one. 2011; 6:e29339. 